\title{
EMPLOYEE MOTIVATION AND CULTURAL INFLUENCE
}

\author{
GAVRIC Gordana ${ }^{1}$, CUKANOVIC KARAVIDIC Marija ${ }^{2}$, PESIC Drasko ${ }^{3}$
}

\author{
${ }^{1}$ Faculty of Business Economics and Entrepreneurship, Belgrade (SERBIA) \\ ${ }^{2}$ Faculty of Business Economics and Entrepreneurship, Belgrade (SERBIA) \\ ${ }^{3}$ Business College of Applied Studies "Prof. Radomir Bojkovic, PhD" Krusevac (SERBIA) \\ Emails: gordana.gavric@vspep.edu.rs, cukanovickaravidicmarija@gmail.com
}

\begin{abstract}
It is well known that, as they perform their work-related activities, people use only a small portion of their creative abilities and potentials, while the largest portion remains unused. If people are motivated, they invest more energy and passion into their work, and their good spirit helps them overcome all types of problems they come across at work. Likewise, motivated employees are in the state of emotional and intellectual satisfaction and feel great devotion to the organization they work for. An old Japanese saying speaks volumes about the importance of motivation: There is no point in carving a Buddha if you do not bring spirit into it. The question of motivation has become quite a challenge for modern managers because motivation is a continuous and changeable process that demands an individual approach.

Numerous factors impact motivation and one of the most significant ones, to which special attention should be paid in the globalization era, is the cultural one.
\end{abstract}

Keywords: motivation, culture, employees

JEL: $M 50$

UDC: $005.32: 331.101 .3 .005 .73$

COBISS.SR-ID: 18172169

\section{Introduction}

In order to achieve success in any segment of our lives, we need motivation. According to one of the definitions, motivation is an activity that drives people to fulfil certain needs. In the context of business, motivation is important because it represents one of the crucial factors that drives employees towards achieving their own business success which then consequently shifts to the organization as a whole.

Due to its positive effects on the employee performance, motivation has become one of the most talked about managerial topics in modern business circumstances. Almost every success-oriented organization today is highly focused on employee motivation [1]. In other words, "no organization in today's competitive world can have superior performance unless every employee is committed to the goals of the organization and unless he/she does not work as an effective team member" [2]. Managers are faced with a difficult task of recognizing why people act in a certain manner in certain circumstances and what can be done to increase their creative contribution, which is the basis of the problem of modern business and development.

Those managers that succeed in discovering what motivates their employees, will also find the key to success because the manager's success depends on the individual success of each and every employee in his/her team.

Motivation is a process that makes ordinary people perform outstanding activities. A motivated employee has a higher level of employee morale, satisfaction and self-confidence, which are all the factors directly influencing the productivity, quality of services they provide, 
survival, growth and development of the organization, as well as the loyalty of employees towards the organization they work for. An adequately motivated team member is energetic, does not fear changes, has a positive approach to challenges and business activities, and as such can boost morale in other employees and lead them towards higher achievements.

Culture and motivation are closely connected. Cultural dimensions are adopted during the socialization of our personalities and then applied throughout our entire lives, which means that employees reflect the elements of their culture (assumptions, beliefs, values, norms) onto their business. Cultural intelligence is a characteristic of every modern person that believes to be a global citizen. It implies openness and skills in understanding certain cultures and their influence on the business process and in that way facilitates business interaction and enables the setting of harmonious atmosphere and successful business relationships.

\section{Employee Motivation}

The importance of motivation in modern business is not only emphasized by managers, but also by psychologists. When asked what the most important thing in human nature that modern managers should be aware of is, two thirds out of 70 interviewees said "motivation".

Understanding the notion of motivation and work satisfaction is of the utmost significance for the creation of work places, organizational culture and climate, the award system, the system of progress, managerial styles [3].

The following definitions of motivation can be found in the literature:

- Motivation is a psychological characteristic of people that influences their level of devotion to a particular thing. It consists of the factors that cause, channel and support human behaviour in a certain desired direction [4].

- Motivation is a set of forces that drives and keeps the person working for the organization, i.e., the person starts one activity and stays focused on accomplishing it [5].

- Work motivation is a psycho-sociological category stemming from the attitude of an individual towards work and his/her readiness to be engaged in the accomplishment of work goals [6].

- The definition of R. Dubin states: "Motivation represents complex forces starting and keeping a person at work in an organization" [7].

- Motivation can also be observed as the strength within a person that will influence the intensity and persistence of voluntary behaviour [8], [9].

- Motivation is a process of initiating, directing and sustaining human behaviour in terms of a certain goal [10].

- From the perspective of managers, motivation can be defined as: an activity that makes people act in a desirable way for the sake of achieving the company's goals and simultaneously for the sake of satisfying the employees' needs [11].

- Everything that makes an activity happen, that directs it and determines its intensity and duration is called motivation [12].

So, based on the abovementioned definitions, it can be said that motivation is an invisible but powerful force that drives people and keeps their behaviour well-directed, that it is a complex process, that it influences the relationship an employee will have with the organization, etc. Likewise, motivation is a continuous and very challenging activity since the "needs of the employees are diverse and changeable and are of different value for each employee" Vujić, 2008, [13].

We can say that the motivational system of the organization is well designed if it enables the organization to: 
- attract and retain highly qualified work force,

- encourage its employees to be highly engaged in the performance of their work assignments and

- set the creativity and innovativeness of employees free in the aim of achieving the desired performances within the organizations.

A good-quality motivational system can be achieved if the managers try to make a connection between employees and their assignments, if they follow their goals, try and provide awards that are personal and connected to the work performance of every individual, enable an atmosphere of learning and progress for their employees, acknowledge salary as a motivational factor, etc. According to Jokić, Bradonjić, Ćoćkalo [14], "strategies in the process of employee motivation that managers mostly use are: communication (good communication between managers and their subordinate structures enables the meeting of the most basic human needs), the manager's attitude towards the employees (this strategy is based on McGregor's XY theory that managers have towards the subordinate members of the organization), designing and enriching work assignments (this strategy is designed in the aim of reducing boredom at the workplace), and behaviour modification (this concept is based on the encouragement of a certain behaviour depending on the consequences such behaviour brings about)." Aleksić Glišović, Jerotijević, Jerotijević [15] state that "modern motivation theories indicate that the motivation that employees feel about their work is less related to material rewards and more to the job design itself". What we should definitely have in mind is the fact that "every company is unique and therefore it needs to independently work out its own and individual way of managing its intellectual capital by using the existing models solely as a base" [16].

One example of a company that returned to the very top of successful companies on a global scale thanks to motivation is the Xerox Company. When Anne Mulcahy became the Managing Director of this company, the company had gone bankrupt due to severe debts, and the employees had been extremely worried for their future. Anne Mulcahy that spent her days paying visits to cities in which the company had offices and talking to the employees, used to say: "Morale and motivation are something I care the most when it comes to the Xerox Company. I think that morale and motivation have the deciding influence on our ability to make results. People should be involved and motivated and feel that they are contributing to something important. I spend most of my time with buyers and employees and I think there is nothing more important any of us leaders could do than to communicate and strengthen the ties with those two most important groups" [17]. Today, thanks to her approach to the challenges she had been faced with and to the efforts her highly motivated employees had invested, the Xerox Company not only recovered, but again became the leader in the development of new digital technologies for colour printing. So, immediate managers play an important role in the motivation of employees and they are the crucial factor in identifying and joining together the needs of the organization with the individual needs, interests and ambitions of their personnel. Modern managers, who have a responsible attitude towards the future of their organizations and are well aware that people are at full liberty to decide where and how they will direct and invest their efforts, should find an adequate model for starting off their motivation because "motivation is a directed activity, not an accidental one" [9].

Even though we can clearly see from the abovementioned example that a proper motivational system provides benefits for organizations, quite often "the simple needs and motives of employees are not well understood and are ignored" [18]. Today's imperative is: "managers must understand the needs and behaviour of people in order to become efficient leaders and the ones who can inspire team members and enable their development" [19]. In their book The Future of Management [20] Gary Hamel and Bill Breen state: "If you want to 
outdo an increasing mass of newcomers thanks to your innovations and the way of thinking, you need to learn how to inspire your employees to give their best every day."

\section{Culture and Motivation}

Motivation is a strong variable in terms of organizational behaviour onto which the values of a particular national culture have a great impact. According to Janićijević [10] "needs, motives, desires of people depend to a great extent on their understanding of the world, human nature and attitude towards people", which are all characteristics of culture.

Geert Hofstede defined, based on the conducted empirical research, the dimensions of national culture most commonly used when exploring how the dimensions of national cultures influence the managerial style. The aim of his research was to explain the specific ways of human behaviour and point to the significance of taking into consideration various cultural elements within the international economy, communication and cooperation. Some of his dimensions that can be useful for the understanding of the process of motivation within organizations are:

- Uncertainty avoidance index. National cultures with a high uncertainty avoidance index (e.g., Germanic cultures, certain Latin-American, Serbian and Japanese national culture) condition a strong need for security in the motivation of employees because people in such cultures have a low level of tolerance to risk and therefore rely on their experts and their knowledge, laws, institutions, rules, order and control. In cultures like these there are deeply rooted beliefs and rules of behaviour which are almost always abide to. On the other hand, in cultures with a low uncertainty avoidance index, managers are free to let their employees make decisions, even the risky ones, because their characteristic is that they will more easily venture out into entrepreneurial endeavours.

- Masculinity vs. Femininity. Cultures with the so-called "male values" (The United States of America) imply a high intensity of the need for achievement, development and self-realization. In such cultures, the most valued things are money, success, ambitiousness, material goods, competitiveness and that's where the secret of motivation hides. In "female cultures" such as the culture of the Netherlands, Sweden, Denmark, Norway and Serbia, dominant values are the quality of life, lack of uncertainty of employment, taking care of our loved ones, preservation of environment, solidarity and equality. Therefore, in such cultures the need for belonging is favoured in comparison to other needs. Possible conflicts are resolved by negotiating and reaching a compromise, and incentives such as flexibility and free time have a favourable influence on employees.

- Individualism/collectivism. In individualistic cultures (The United States of America) the relationship with workers is mostly contractual, i.e. a worker offers his/her work in exchange for a salary which is in proportion to the number of work hours. Workers in cultures such as these like to solve problems on their own, to independently make decisions and they believe that every worker should be awarded in accordance with the level of his/her contribution and the success they achieve. In collectivistic cultures (Japan, as well as the culture of Serbia) people want to be perceived as members of a certain group in which they take care of each other, take responsibility for each other and look after each other. The relationship between workers and employees is emotional, companies take care of their employees and expect their loyalty in return. The awards are equally distributed inside the group. So, in collectivistic cultures, the most important need is that for belonging, while in individualistic cultures the most 
prominent need is that for achievement, which is a useful information for the process of motivation.

Two completely different cultures are the cultures of China and America, which has been confirmed by research on motivation of their employees and their approach to work. The research on the comparison of the Chinese and American employees' motivation [21] showed that Chinese employees don't find the interestingness of work as well as being up-to-date with happenings at their workplace to be important factors of motivation, unlike their American colleagues. Likewise, Chinese employees don't think they should be specially awarded for performing an important or difficult assignment, while the Americans find that quite important. Another important factor is the loyalty of managers (superiors) to their employees.

Chinese workers think it is important to have a strong relationship between the employees and their managers because their culture nurtures strong interpersonal relations. American employees described the relationship between managers and employees as something of poor influence on their work activities. The biggest differences are the interpersonal loyalty and work conditions that Chinese workers emphasize. Also, the research showed that Chinese managers are far better acquainted with the desires and needs of their subordinates than Americans are. The consequence of that is that Chinese culture nurtures a strong interpersonal relation, while the Western culture separates work from friendship and by doing so puts limitations to the nurturing of interpersonal relationships within the organizational culture [21].

In a research that aimed at identifying motivational factors in regards to employees in Serbia [22], what makes employees satisfied with their work and increases their performance, a total of 500 employees from 15 different small and medium-sized organizations took part, out of whom 213 were women and 287 men. By analysing the collected data, six relevant factors which represent 20 manifest items concerning work satisfaction were identified. The first place was taken by interpersonal relations, the second by the stability of the workplace, the third by the organizational management, the fourth by freedom and creativity at work, the fifth by the possibility of influencing improvement and progress and the sixth by the style of control. According to the results, not all identified factors have the same significance, and the first three factors have the greatest relevance in explaining the variance: first - interpersonal relations; second - stability of the workplace; third - organizational management.

The identified factors are in complete accordance with the characteristics of the Serbian culture as described by Hofstede. Proper interpersonal relations, since the Serbian culture is a "feminine culture" characterized by people taking care of the loved ones, solidarity and equality, the need for belonging and solving conflicts by negotiating and reaching a compromise. Also, our culture is collectivistic and, in its people, want to be seen as members of a particular group wherein they take care of each other, take responsibility for each other and look after each other, and the relationship between employees and employers is not strictly business-based, but rather emotion-based. Further on, in Serbia, in which the culture is feminine and has a low uncertainty avoidance index, the stability of the workplace is an important motivational factor since people simply do not like big changes and risk.

Managerial method has a significant impact on the workload and the solving of possible conflicts. According to our culture's characteristics, employees in Serbia expect equal treatment of all employees, a fair award system, flexibility and free time.

\section{Conclusion}

Employee motivation has become a crucial phrase and a dominant preoccupation of modern managers and organizations on a highly competitive global market. The way an organization manages its human resources can help it in creating and sustaining its 
competitive advantage. The basic goal of every manager would be to create such a business environment in which competent people perform their activities with high levels of enthusiasm, energy and motivation. We can freely conclude that the crucial role of leaders in regards to achieving better work and business results is in inducing creative energy, i.e., motivation. Motivation is closely connected to the phenomenon of culture and that is a fact which must not be neglected in the globalization era.

\section{REFERENCES}

[1] Vukajlović Đ. \& Ostojić B. (2016). Motivacija zaposlenih. Vojno delo, 6/2016, pp. 307-315.

[2] Radosavljević Ž., Ćilerdžić V., Dragić M. (2017). Employee Organizational Commitment. International Review, No. 1-2, pp. 18-26.

[3] Tanasijević Z. (2011). Zadovoljstvo poslom - ključni pokazatelj motivacije zaposlenih. Sociološka luča, V/1, pp. 116-123

[4] Jovanović B. G. \& Božilović A. S. (2017). Motivacija i politika upravljanja ljudskim resursima u organizaciji. Tehnika - menadžment, 67 (2017) 1, pp. 117-125.

[5] Čerović S. (2012). Upravljanje ljudskim resursima u hotelijerstvu. Beograd.

[6] Dobre, O. (2013). Employee motivation and organizational performance. Review of Applied SocioEconomic Research, Vol. 5, Iss. 1, pp. 53-61

[7] Vujić D. (1995). Motivacija za rad kreativnog kadra u uslovima krize društvene i organizacijske sredine. Psihologija, pp. 339-354.

[8] Pinder C. C. (1998). Work motivation in organizational Behavior, Upper saddle River, NJ, Prentice Hall

[9] Stepanov S., Paspalj D. \& Butulija M. (2016). Motivacija zaposlenih kao ključni pokazatelj zadovoljstva poslom. Ekonomija teorija i praksa, godina IX, br oj 2, pp. 53-67.

[10] Janićijević N. (2008). Organizaciono ponašanje. Datastatus, Beograd.

[11] Ugrinov D. \& Stojanov A. (2013). Menadžment i motivacija zaposlenih. Pravno-Ekonomski Pogledi, br. 1/2013, pp. 1-10.

[12] Šuković F. (1987). Psihologija rada i organizacije. Zavod za udžbenike i nastavna sredstva, Beograd.

[13] Samardžić M., Živković D., Rajić Z. \& Jelić S. (2016). Human resource management at "AD Imlek belgrade". Economics of Agriculture, 2/2016, pp. 681-697.

[14] Jokić S., Bradonjić D, \& Ćoćkalo D. (2012). Motivacija i motivacioni faktori zaposlenih. Megatrend revija, Vol. 9, No 4, 2012: pp. 201-216.

[15] Aleksić Glišović M., Jerotijević G. \& Jerotijević Z. (2019). Modern approaches to employee motivation. Ekonomika, Društvo ekonomista “Ekonomika” Niš, Vol. 65, № 2, pp. 121-133.

[16] Pravdić P. \& Kučinar R. (2015). Značaj upravljanja intelektualnim kapitalom. Trendovi u poslovanju, godina III, broj 5, sveska 1/2015, pp. 11-18.

[17] Williams C. (2010). Principi menadžmenta - MGMT. Datastatus, Beograd.

[18] Živković D. Ž, Popović N. \& Jelić M. (2003). Upravljanje istraživanjem i razvojem - (R \& D menagement). Bor: DŠIP Copper.

[19] Heler R. (2009). Priručnik za menadžere. Profil knjiga.

[20] Hamel G. \& Brin B. (2009). Budućnost menadžmenta. Asee, Novi Sad.

[21] Šalić D., Golijanin D. \& Alčaković S. (2015), Motivacija zaposlenih u Srbiji. Synthesis, pp. 694-698.

[22] Čukanović Karavidić M. (2018). Savremene menadžment formule uspeha; Upravljanje promenama usvajanjem novih znanja i veština, novih inovativnih i kreativnih tehnika, upravljanje vremenom, stresom i komunikacijom, doktorska disertacija, Univerzitet za poslovni inženjering i menadžment, Ekonomski fakultet, Banja Luka.

\section{Article history:}

Received 24 March 2020

Accepted 26 May 2020 